\title{
On A Monumental Brass In Christ's Church Cathedral, Dublin
}

\section{Sir Philip Grey Egerton Bt., M.P.}

To cite this article: Sir Philip Grey Egerton Bt., M.P. (1879) On A Monumental Brass In Christ's Church Cathedral, Dublin, Archaeological Journal, 36:1, 213-218, DOI: 10.1080/00665983.1879.10851879

To link to this article: http://dx.doi.org/10.1080/00665983.1879.10851879

册 Published online: 14 Jul 2014.

Submit your article to this journal

Џll Article views: 1

Q View related articles 두 


\title{
abe arcbaealogical Journal.
}

\author{
SEPTEMBER, 1879.

\section{ON A MONUMENTAL BRASS IN CHRIST'S CHURCH CATHEDRAL, DUBLIN.}

By SIR PHILIP GREY EGERTON, Bt., M.P.

In the course of last December (1878) I received through the courtesy of Mr. Vaughan, of Edwardes Square, Kensington, a careful rubbing of a brass tablet in the recently restored cathedral church of Christ's Church, Dublin. As it raises some points of genealogical and heraldic interest a short account of it may not be unacceptable to the Archæological Institute. The brass is of small dimensions, being only seventeen inches square. It is fixed in a framewrork of stone projecting slightly from the south wall of the south transept, and is associated with three shields sculptured in stone, two above and one below. On one of these the Grey motto is inscribed, but the heraldic details are indistinguishable in all. The whole area of the brass plate is covered with heraldic details and embellishments, surrounded by a flowing scroll border. The centre of the field is occupied by the shield containing forty quarterings, within a garter. The supporters are: dexter, a Lion rampant, argent; sinister, a Wyvern, or. The helm is enriched by a flowing lambrequin, and is surmounted by the Falcon and Columbine branch, the Grey crest. In the upper dexter angle there is a capital letter $\mathrm{A}$, and in the sinister a G, the initials of Arthur Grey. Below the garter is the motto "At viNCET PAUPERIAM viRTUS" on a scroll upon which the supporters rest. Below the scroll are represented two coffins, the one on the right having the figure of an infant on the lid, and that on the 
left that of a baby in swaddling clothes. Beside each coffin is a shield quartering: 1. Grey. 2. Hugh Lupus, Earl of Chester. 3. Strongbow, Earl of Pembroke. 4. Marshall, Earl of Pembroke. At the bottom of the plate is the following inscription in capital letters. "HERE LIETH BURIED THE SECOND AND THIRD SONNES OF THE Right Hoxorable Sir Arthure Grey, Knight of the Order. Lord Grey of Wilton, and of the Lady JaNA SibILla hIS WIFE, WHYCH CIILIJReN DIED IN THE CASTEL OF DUbLIN IN THE TIME OF HIS DEPUTATION HERE."

Arthur Lord Grey de Wilton, к.G., who caused this memorial to be erected to the memory of two of his children, was descended from a long line of illustrious ancestors, distinguished by their abilities in the discharge of the high civil and military duties entrusted to them by the successive sovereigns under whom they served. Dugdale in his Baronage makes no notice of the Grey family previous to the reign of Richard I, but according to Banks the common ancestor of the several collateral branches of Codnor, 'Thurroch, Wilton, Ruthyn, and Groby, was Rollo or Fulbert, chamberlain to Robert, Duke of Normandy, "of whose gift he had the castle and honour of Croy, in Picardy, from whence his posterity assumed their surname" (afterwards written de Grey).

In a descent in my possession certified by the College of Heralds the line is traced up to Sir John de Grey, who was succeeded by Arnold, Reginald, and Henry the father of the aforesaid Henry de Grey, who married Isolda, daughter and heir of Hugh de Bandolpl.

The Grey descent, as given in my family pedigree, blazoned by Randle Holmes, the Chester Herald in the year 1665 , accords very closely with that recorded by Banks in his extinct Baronage. The earliest entry is as follows:- "Rowland of some called Ffulbert had issue Arletta concubine to Robert Duke of Normandy ffather to William the Conqueror, and John de Gray which lived in the Conqueror's time, who had issue John, who had issue Arnold, who had issue Reginald Lord of Rotherfield and Waterton, who had issue two sons, John de Gray Lord of Stoke by his ffather's guift, and Henry Lord Gray of Waterton and Rotherfield obiit $33^{\mathrm{d}}$ of 
Hen. I." His son Sir John Grey, "the first called Gray," obiit 12 th of King John, and his son Henry, by his wife Ellianor, daughter of Roger, surnamed the good Earl of Clare, is the first of the family mentioned by Dugdale. Whatever ambiguity may envelope the early genealogy of the family, all competent authorities agree in the unbroken descent from Henry de Grey, clramberlain to Richard I, who conferred upon him the grant of Thurrock in Essex, which grant was confirmed by John. His son Richard was the progenitor of the Greys of Codnor, and his son Sir John was the ancestor of the Wilton and Ruthyn branches. This Sir Jolnn was justice of Chester in the 30th of Henry III, and was distinguished for his loyalty to his sovereign during the wars with the barons. His son, Sir Reginald, was also justice of Chester in the 54 th of Henry III, and had summons to Parliament, among the barons of the realm, from 23rd of Edward I to the 2nd of Edward II. He married Maud, daughter and heiress of William, Lord Fitzhugh, by Hawise, daughter and heiress of Hugh de Longchamps, by which marriage he became possessed of Wilton Castle in Herefordshire. (Dugdale asserts in his Baronage that Reginald, Lord Grey, married the daughter of Hugh de Longchamps, whereas this lady was his wife's mother). In addition to this, he obtained from the king Ruthyn Castle in North Wales, in remuneration for his services. John, his son, was made justice of North Wales and governor of Carnarvon Castle, in the 10th of Edward II ; and from his son Roger, by his second wife, Maud, daughter of Ralph, Lord Basset, is descended the Ruthyn branch of the family.

For many subsequent generations the Lords Grey of Wilton were distinguished for their loyalty to the throne; the trust that was reposed in them by the several sovereigns under whom they served, and the zeal and ability with which they discharged the duties, civil and military, devolving upon them by nature of the important posts to which they were appointed. These services have been so fully recorded by Hollinshed, Dugdale, and other chroniclers and historians, that it is needless to repeat them on this occasion. The successive heads of the family contracted marriages with the highest grades 
of society of the periods in which they lived; and, as many of the alliances were with heiresses, the familyshield became enriched by a multitude of illustrious quarterings. Forty of these are engraved on the brass in Christchurch Cathedral, Dublin; but I have a list drawn up by the College of Heralds, in which no less than sixtytwo are enumerated as appertaining to this branch of the family. Eighth in lineal descent from the above named John came William Lord Grey, father of Arthur, who was the most distinguished of all the race for his ability, both in civil and military emergencies. The details of his active, yet chequered life, in the reigns of four sovereigns, are fully given by the several historians who have recorded the events of the period, and also in the Commentary of the services and charges of William Lord Grey, published by the Camden Society, from a manuscript written by his son Arthur, for the use of Hollinshed. In reward for his long and distinguished career he received in $\$ 1557$ the Order of the Garter, but he did not live long to enjoy it, as he died in 1562, when Arthur Lord Grey, his son, by his marriage with Mary, daughter of Charles Somerset, Earl of Worcester, succeeded to the family honours as fourteenth baron. He accompanied his father in many of his military appointments, and was with him at the siege of Guisnes, and in his Scotch campaign in 1560 . He had summons to Parliament in 1566 , and received the honour of the Garter in 1572. He was appointed Lord Deputy of Ireland in July 1580, and as he was recalled in August 1582, the date of the monumental brass recording the deaths of his two sons must be between these periods. Lord Grey was twice married. His first wife was Dorothy, natural daughter of Richard Lord Zouche of Haryngworth, by whom he had an only daughter, Elizabeth, married to Francis, only son of Sir John Goodwyn of Overwinchindon, in the county of Bucks. The settlement made in this marriage is dated the 28th of Elizabeth, 1586, and is signed by Arthur Lord Grey, Sir John Goodwyn, and Francis his son. This deed only came into my possession this year.

Arthur married secondly Jana Sibilla, daughter of Sir Richard Morrison of Cashiobury, and relict of Francis, 
second Earl of Bedford. By this marriage he had Thomas, who, disiegardful of the fair fame of his ancestral precursors, became a participator in the Raleigh plot, and being convicted, was committed to the Tower, where he died, unmarried, in 1614.

The only other son of Arthur found recorded in the genealogical authorities was William, who was born in the year 1588, and died at Magdalen College, Oxford, in 1605-6. This son is thus referred to in Wood's Athence Oxoniensis: "John Dunster had several copies of verses printed in various books, especially that made by the Society of Magdalen College, on the death of a noble young man of that house, named William Grey, son of Arthur Grey, Baron of Wilton." A monumental brass was placed to his memory in the Chapel of Magdalen College, bearing the following inscription; " Hic situs est Gulielmus Grey natu minor filiorum Arthuri Grey Baronis de Wilton obiit Februarii die 18 An. Dom. 1605 completis ultra annos rtatis integros 17 quatuor etiam mensibus." This brass had been removed from its position, and was deposited in the Bursary of the College ; but, through the kindness of the Dean and the authorities of the College, it has now been replaced. As William was born in the year 1588 , it will be seen by the Christchurch Cathedral brass that he was the fourth son of his parents, who had hitherto only been credited with two sons. In addition to the male issue, Arthur had an only daughter by his second wife, Bridget, who, on the death of her brother Thomas, became heir of the whole blood of this ancient family. She married in 1609 Rowland, son of Sir John Egerton of Egerton, knight, who was subsequently in 1617 created a baronet. On the death of the late Farl of Wilton, the lineal descendant of this marriage, the male line of the elder house became extinct, and the baronetage devolved upon John Egerton of Egerton and Oulton, Esq., the lineal descendant of Sir Philip Egerton, Knight, the second son of Sir Rowland, and the earldom passed to the second son of the first Marquis of Westminster, through his mother, sole daughter of the said last Earl.

Having briefly sketched the genealogical interest of this brass, I add a few remarks on its heraldic bearings. The shield contains, as before stated, 40 coats; of these 
the following have been identified :- -1, Grey de Wilton; 2, Glanville ; 3, Fitzhugh ; 4, De Longchamps ; 5 , Rokele ; 6, Clare ; 7, Consul ; 8, Botetourt ; 9, Strange ; 10, Talbot; 11, Talbot; 14, De la Vache; 15, Fitz Osbert; 16, Bruere; 17, Hastings, Earl of Pembroke ; 20, Waltheof, Earl of Northumberland ; 21, Mac Morough, King of Leinster ; 23, Hugh Lupus, Earl of Chester : 24, Marshall, first Earl of Chester; 25, Randal, second Earl of Chester; 26, Meschines, Earl of Chester ; 27, Cantelupe ; 32, Valance, Earl of Pembroke ; 34, Fitz Oates ; 36, Muchesney ; 37, Marshall, Earl of Pembroke; 38, Strongbow, Earl of Pembroke; 39, Randal, third Earl of Chester ; 40, Hastings. The motto is not the one usually used by the family. Sir Harris Nicolas, in his History of the Order of Knighthood, quotes the rhymes of Tashe on Arthur Lord Grey's motto, "Forte en Loyalte ;" and I find no record of "Ut vincet pauperium virtus" in any books of reference I have been able to consult. The only remaining point worthy of observation is the inversion of the supporters. The Grey supporters, as recorded in the Herald's office, and as shewn on the Garter plate of William Lord Grey de Wilton, are, dexter a Wyvern, sinister a Lion rampant; whereas on the brass the Lion occupies the dexter, and the Wyvern the sinister position. The latter arrangement is that now borne by the elder branch, the transposition having been made, for a difference, when Sir John Egerton obtained the Royal warrant for adopting the name of Grey before that of Egerton, and using the Grey arms quarterly with those of Egerton. 